\title{
Change, Consilience, and Good Things Happening at ASHS
}

\author{
ASHS 2011 Presidential Address: Fred T. Davies \\ Waikoloa, Hawaii, 28 September 2011
}

\section{Introduction}

I grew up in central New Jersey, working on potato farms in the summer as a teenager, but never considered horticulture as a career opportunity. During my senior year at Rutgers, I decided that before being caught up with a career, job, family, and responsibility - to travel the world after graduation, which I did with my best friend, who happened to be a horticulturist — Jaime Lazarte. Jaime had just finished his Master's degree with Dr. Fred Hough, who had a significant impact on many 20th century pomologists and current practitioners. We hitchhiked and backpacked around the world for a whole year-on about $\$ 2800$ each! Our travel focused on agriculture, and we visited banana, tea, coffee, and date palm plantations, as well as commercial nurseries, greenhouses, tree fruit production, and agricultural processing and storage facilities. I got hooked on the international niche opportunities of horticulture in producing high-end value crops for exportation. I still use some of those international experiences when I teach and do research. And I have been fortunate to have since worked on Fulbright fellowships, teaching and doing research in Mexico and Peru. With globalization, the niche opportunities for high-value horticultural crops are as strong as ever! Even the NASA-sponsored low pressure production systems we study in our lab are based around salad bowl crops. There will be no long-term habitation on the Moon or Mars without horticulture! And it's not just human nutrition, but how horticulture impacts all of us in the quality, psychology, and value-added aspects of our lives.

\section{Mission of ASHS}

The ASHS mission is to be "a cornerstone of research and education in horticulture and an agent for active promotion of horticultural science." While this core value remains constant, ASHS has the continual challenge of reinventing and positioning itself to be more attuned to a smaller, but viable, membership base, and to reach out, attract, and become more relevant to industry, students, faculty, and the public. And ASHS is not just "American." We are very much an international organization. Over one-third of our membership is from outside the United States, and over half of the articles published in the Journal of the American Society for Horticultural Science, the most prestigious horticultural journal in the world, are from authors residing at international institutions.

\section{What Brings Us to ASHS?}

ASHS is about relationships. It is about the collegiality, personal and professional relationships developed. As the other Davies, Fred S., coined it: that "social fabric." It is the opportunity to network and develop collaboration. It is the relationships, collegiality, and networking that draws a majority of us to ASHS - not just the technical dissemination of the science. However, there are major challenges in connecting with Generation Y, also known as the Millennial Generation - the children of us baby boomers. While millennials are quite savvy about communications, media, and digital technologies, they don't join structured organizations as in previous generations. So how does ASHS do a better job of attracting them? We also need to develop a long-term strategy for attracting Generation $\mathrm{Z}$, the internet generation, which currently ranges from age 15 and younger.

ASHS is about volunteering. I am impressed with your volunteerism and ENTHUSIASM! Last year as President-elect, I was charged with filling ASHS committee member positions. Of the 75+ letters I sent out -ALL came back positive with folks eagerly willing to serve. As your Executive Director, Mike Neff, remarked: "That doesn't surprise me .... we've got great people in this Society ready to serve! Very encouraging."

ASHS is also about leadership. Students and young faculty are the new blood of this organization. The very active undergraduate club program, Association of Collegiate Branches (ACB), has been a great reservoir for developing new leadership talent. The $\mathrm{ACB}$ was designed to encourage undergraduate participation in the Society, provide a forum for exchange of club and professional ideas, encourage a greater understanding of regional and national horticulture, and act as an official body for undergraduate horticulture student contributions. There are individual and university club competitions. The ACB is student driven, with strong leadership shown by a number of undergraduate students, including 2011 ACB President, Taylor Payne, and dedicated faculty advisors such as Richard Harkess, Curt Rom, Dan Lineberger, and Dave Reed. Young faculty can become involved with leadership opportunities by joining Working-Groups, which are the driving force of ASHS creativity, and other national and regional ASHS committees. These opportunities enable a young (or older) faculty member to build up a professional portfolio showing leadership in research, extension, and teaching-important for developing strong promotion and tenure packages.

\section{Challenges \& Opportunities}

Today, horticulture and ASHS stand at a crossroad that offers much opportunity. While land-grant horticultural departments are being merged into plant science departments, more horticulture is being taught than ever in non-land-grant universities, colleges, and technical schools. A majority of ASHS membership has been from the land-grant system, which is contracting. How do we adapt and broaden our client base to better service the non-land-grant institutions? Globalization, marketing, labor, environmental issues, energy and water-usage issues, and consolidation are having a profound effect on the viability and profit margins of the horticultural industries. Industry is having as tough a time, as are academic institutions. So is the USDA-ARS with major cut-backs in funding and staff.

\section{Adapting to Change}

Change is afoot about how we view the quality, nutrition, production, origin, and safety of foods we consume. In California, the fastest growing segment of farmers is female, nonAnglo, and intensively farming small acreage with horticultural crops. "Food miles," community supported agriculture (CSA), "slow food," "Agriburbia," and permaculture are issues and opportunities impacting horticulture. Young farmer associations are cropping up around the U.S. (http://www.payoungfarmers. com/). The acronym CSA is known to the readers of the trendy gourmet magazine Food $\&$ Wine. There are national and international movements to buy locally grown food and "know your farmer." In 1903, when ASHS was established, over $50 \%$ of the U.S. population lived on farms. Today, less that $2 \%$ of the population is involved with agriculture.

The average supermarket item is transported over 1200 miles from farm to fork. This is an unsustainable system based on petroleum. Even Wal-Mart has picked up on leveraging "food miles." While this conglomerate has never been driven by altruism, it is quite astute at seizing market opportunities. Wal-Mart has long focused on costsaving efficiency and was an early adopter of food miles as a profit-maximizing strategy. The company has embraced the environmental benefits of supply chain efficiency. The mega-retailer, which tops the Fortune 500 list and employs around 2 million people worldwide, is focused on going green by reducing energy consumption, using renewable energy, producing zero waste, and selling sustainable products. The company is dramatically increasing sales of organic products, and using more local farm purchases to save money on truck fuel costs and refrigeration. According to Wal-Mart's Produce Division leader, Ron McCormick: "Our whole focus is: How can we reduce food miles?" The company strategy is to purchase a broader variety of produce based on what's available in each region, rather than insisting on a "monoculture" of produce at stores nationwide. Despite the 
current gloom and doom from the media, there are niche opportunities for horticulture if we adapt. In Machiavelli's The Prince, the hardest thing for an organization to do is to changesome people lose, some gain-but most important is what is best for the organization; "he who neglects what is done for what ought to be done, sooner effects his ruin than his preservation." In horticulture and ASHS there are new strategic prospects for horticulture production, research, teaching, and extension outreach-are we willing to seize the moment and adapt to these opportunities?

\section{Consilience}

Edward Wilson popularized this rare word when he used it in the title of his best-selling book Consilience: the Unity of Knowledge (1999, ISBN: 067976867X). It means "a jumping together," and in his book he encourages those who study the sciences, the humanities, and the arts to bridge the gaps between their narrow specializations and so link together all the branches of learning - an aim that goes back to the thinkers of the Enlightenment. Wilson discusses methods to unite the sciences with the humanities. He uses "consilience" to describe the synthesis of knowledge from different specialized fields of human endeavor that can be part of interdisciplinary research.

\section{Consilience and Horticulture}

When you get down to it-successful programs in horticulture use consilience. This evolution of collaboration with horticulture and other disciplines has been going on for some time. We see it in thriving programs addressing societal issues, such as health, obesity and nutrition. A good example includes the Junior Master Gardener Program (JMG) (http://jmgkids.us/). We are all painfully aware of the societal problems faced in the United States - from losing too many young kids in elementary school who are turned off to "boring, irrelevant" science and math, to obesity and nutrition issues, to apathy, lack of volunteerism, and unwillingness to take responsibility and leadership. The JMG program uses the "McDonald's Approach": you get to the family through the kids. Building youth leaders by utilizing environmental sciences to develop academic skills, character education, service learning, Ag awareness, nutrition-eating habitsfruits and vegetables. Lisa Whittlesey, who leads the program at Texas A\&M University, has partnered the JMG with nutritionists, educators, public health professionals, the medical community, physical activity experts, and sociologists - with support from the USDA, NIH, National Wildlife Foundation, Peace Corps, Borlaug Institute for International Agriculture, Center for Disease Control, a host of other organizations - and a recent $\$ 5$ million USDA-NIFA grant aimed at battling obesity.

Another horticultural program built around consilience is the Cancer Prevention Laboratory (CPL) that Henry Thompson runs in the Department of Horticulture and Landscape
Architecture at Colorado State University (http://www.cropsforhealth.colostate.edu/). The CPL conducts both pre-clinical and clinical research, the goal of which is to identify practical solutions that will empower an individual to adopt lifestyles that achieve and maintain a lower risk for cancer. They use consilience in tackling chronic disease prevention. This includes developing crops for health, integrating plant breeders, producers, retailers, biologists, chemists, health care professionals - and ultimately consumers. Because our food supply is a primary source of many chemicals that contribute to the interplay of forces that promote as well as prevent the development of cancer, the CPL is part of the College of Agricultural Sciences. This permits cancer researchers to regularly interact with investigators responsible for decisions that impact the health characteristics of the foods ultimately made available to the consumer. The CPL judges that enhancement of the health benefits of the foods made available to consumers could have global impact on human health and well being.

\section{Storms on the Horizon}

While all this is fine and swell, the cost of good, nutritious food continues to spiral. It is currently much cheaper to buy a high calorie, high salt, starchy meal at a McDonald's or some other fast-food joint - than to purchase fresh fruits and vegetables on a regular basis. And wholesome food continues to become more expensive and less accessible to the poor in America and other regions of the world - these are the folks who spend a disproportionally higher percentage of their income for food than the rest of us. The latest 2010 census reports that the U.S. population is $86 \%$ urban-we don't live on farms anymore, where we can grow our own fresh fruits and vegetables.

\section{How to Feed 9 Billion People?}

By the middle of the 21 st century, the world population will increase from 6.8 billion to more than 9 billion. Forecast increases in crop productivity from biotechnology, genetics, and agronomics will not be sufficient to meet food demand, and resource limitations will constrain the global food system. For the first time in human history, food production will be limited on a global scale by the availability of land, water, and energy. Food issues could become as politically destabilizing after 2050 as energy issues are today. More efficient technologies and crops will need to be developed to address this challenge.

\section{Alarming Reduction in Land-Grant System Support}

While the U.S. public investment has been a great return on investment, with benefit-cost ratios of 20:1 and higher, there has been a redirection of federal agricultural research funds away from productivity-oriented research and development for the past 30 years. Since the early 1990 s, U.S. agricultural productivity has slowed to a crawl, averaging less than $1.2 \%$ per year between 1990 and 2007 (Pardey and Alston, 2011. For want of a nail: The case for increased agricultural $R \& D$ spending). There is a direct link between the reduction in public funding and slowdown in agricultural productivity growth. The failure to revitalize federal funding for agricultural productivity-oriented research will have adverse affects on all U.S. households, particularly the poorest households that benefit most from lower food prices. As Pardey and Alston argue - with increasing food prices, it is misguided to continue to undermine agricultural productivity by limiting federal investments in agricultural research, particularly productivityoriented research - in favor of agricultural research dealing with the environment, nutrition, health, and a host of other societal problems. It is a no-brainer: there are growing hunger and food-security problems confronting the U.S. and the world. Federal and public funds need to be focused on research that improves agricultural productivity and reverses the slowdown in U.S. farm productivity. The market has begun to signal the beginning of the end of more than a half century of global agricultural abundance. So what are these politicians, policy makers, and a disengaged public thinking?

What good is the wholesome nutrition of horticultural crops that a large portion of the U.S. and international population cannot afford to routinely buy? Agricultural productivity, food security, environment, health, nutrition, obesity are ALL interconnected. But we need to maintain a critical level of research and development for enhancing productivity.

\section{There is Hope}

ASHS is participating in a "Coalition of Science for Food and Agriculture in the 21st Century" with other major disciplines and stakeholders. The USAID and USDA have instituted a $\$ 1.3$ billion Feed the Future (FTF) program to: 1) address the root causes of hunger that limit the potential of millions of people, and 2) establish a lasting foundation for change by aligning resources with country-owned processes and sustained, multistakeholder partnerships. There will be opportunities for horticulture in this arena. There has never been a greater need than NOW for using consilience in thinking outside the box to address these pressing current and future problems!

\section{Good Things Happening at ASHS}

There are new opportunities with ASHS Professional Certification programs. How can ASHS be more effective in helping industry find and employ qualified horticulturists? How do we educate the next generation of professional horticulturists? A major concern of all horticultural industries is attracting young, talented employees. How can we better enhance the professionalism and development of horticulturists enrolled at 2- and 4-year institutions, and at land-grant universities where "Horticulture" has become embedded in "Plant Science" departments? The recent 
development of the ASHS Certified Horticulturist program (http://www.ashs.org/) is also an opportunity to bridge with industry and make ASHS more relevant to horticultural practitioners - those folks working in the profession who need to improve their skill sets.

ASHS is financially strong. We are predominantly a publishing house. It is the revenue from our publications that supports the organization and pays for membership activities, which membership dues only partially cover. Annual meetings are a break-even process. The ASHS refereed publications, Journal of the American Society for Horticultural Science, HortScience, and HortTechnology, remain strong. Much of the credit goes to the editorial leadership of Neal De Vos and Ron Robbins, and volunteer reviewers, who have helped to dramatically streamline the review process. In January of 2011, the ASHS leadership gave open electronic access to ASHS refereed publications for back issues from 2008 and prior, with access to occur in future years to publications of three years and older. This is an important gift to the world, particularly to those in developing countries who need access to our journals, which were previously cost-prohibitive as hard copies.
The development and better utilization of web-based technology greatly enhances ASHS capabilities. The public face of ASHS is our webpage, which has dramatically improved under the guidance of Tim Rhodus, ASHS Editor of Digital Information. The public can even access podcasts of the 2011 Hawaii conference.

The Farm Bill with the Specialty Crop Research Initiative and Specialty Crop Block Grants program are a real opportunity for the discipline of horticulture and ASHS. The move of ASHS to hire a national issues consultant, Jonathan Moore, and the development of the National Issues Task Force (NITF) by John Clark and Thomas Björkman to make ASHS more proactive as an organization on Capital Hill-is vital.

ASHS has had very strong and stable leadership over the years from Mike Neff, ASHS Executive Director, and Tracy Shawn, Director of Meetings and Assistant Executive Director, who have been with ASHS, respectively, for 25 and 12 years. There has been a downsizing and enhanced efficiency of a very dedicated ASHS Headquarters staff.

The ASHS Board of Directors (BOD) is deeply committed to listening to the membership about what we need to be doing better.
There was an outstanding 31\% membership response to the recent September 2011 membership survey. Your BOD and Headquarters' leadership will be looking closely at your concerns and suggestions.

\section{Final Word}

When Spencer Beach, L.H. Bailey, and other pioneers formed the ASHS in 1903, it was their vision and goal that horticulture would develop into an applied, translational SCIENCE that would link the basic sciences (botany, biology, chemistry) with the development of new production systems, goods, and services for industry and the consumer. They were hugely successful in their endeavor. It is our challenge to make sure that future generations of horticulturists have the same opportunities for success.

It has been humbling, and a great honor to serve ASHS as your president. While we face significant challenges, there is no segment of agriculture better situated than ASHS and horticulture to address societal problems, and to produce niche markets with new horticultural products and services. New opportunities always occur with change. Horticulture is ubiquitous - and a great, noble profession and translational discipline. Humankind needs us to flourish and survive! 